\title{
FREQUENCY OF TOXOcara INFECTION IN CHILDREN ATTENDED BY THE HEALTH PUBLIC SERVICE OF MARINGÁ, SOUTH BRAZIL
}

\author{
Márcia L. PALUdO(1), Dina L.M. FAlAVignA(2), Guita R. ELEFANT(3), Mônica L. GOMES(2), Magda L.M. BAGgiO(4), Luciano B. AMADEI(4) \\ \& Ana Lúcia FALAVIGNA-GUILHERME(2)
}

\begin{abstract}
SUMMARY
The lack of specific laboratorial diagnosis methods and precise symptoms makes the toxocariasis a neglected disease in Public Health Services. This study aims to determine the frequency of Toxocara spp. infection in children attended by the Health Public Service of Hospital Municipal de Maringá, South Brazil. To evaluate the association of epidemiological and clinical data, an observational and cross-section study was carried out. From 14,690 attended children/year aged from seven month to 12 years old, 450 serum samples were randomly collected from September/2004 to September/2005. A questionnaire was used to evaluate epidemiological, clinical and hematological data. An ELISA using Toxocara canis larval excretory-secretory products as antigen detected $130(28.8 \%)$ positive sera, mainly between children from seven month to five years old $(\mathrm{p}=0.0016)$. Significant correlation was observed between positive serology for Toxocara, and frequent playing in sandbox at school or daycare center $(\mathrm{p}=0.011)$ and the presence of a cat at home $(\mathrm{p}=0.056)$. From the families, $50 \%$ were dog owners which exposed soil backyards. Eosinophilia ( $\mathrm{p}$ $=0.776$ ), and signs and symptoms analyzed (fever $\mathrm{p}=0.992$, pneumonia $\mathrm{p}=0.289$, cold-like symptoms $\mathrm{p}=0.277$, cough $\mathrm{p}=$ 0.783 , gastrointestinal problems $\mathrm{p}=0.877$, migraine $\mathrm{p}=0.979$, abdominal pain $\mathrm{p}=0.965$, joint pain $\mathrm{p}=0.686$ and skin rash $\mathrm{p}=$ $0.105)$ could not be related to the presence of anti-Toxocara antibodies. Therefore, two asthmatics children showed titles of 1:10,240 and accentuated eosinophilia $(\mathrm{p}=0.0001)$. The authors emphasize the needs of prevention activities.
\end{abstract}

KEYWORDS: Seroprevalence; Toxocara spp.; Children; Public service; Risk factors.

\section{INTRODUCTION}

Human toxocariasis is a zoonosis spread worldwide. It shows different prevalences ${ }^{1,2,3,5,6,10,11,16,28,31}$ depending on innumerable factors, such as poverty, human contact with soil contaminated by dog feces, and residence in rural areas. Toxocara canis and Toxocara cati, helminths belonging to the family Ascarididae, are common intestinal parasites of dogs and cats ${ }^{8,32}$. Toxocara is the main genus responsible for the Visceral Larva Migrans (VLM) syndrome or toxocariasis in humans, T. canis being the primary causal agent of this parasitosis ${ }^{33}$.

Human infection occurs through accidental ingestion of embryonated eggs of Toxocara spp. found in soil and sand contaminated by animal feces ${ }^{25}$. The migration and persistence of nematode larvae in unusual host organs cause the VLM syndrome ${ }^{1,17}$. The larvae cause mechanical injury as they migrate through the viscera, inducing the host to develop different degrees of inflammatory response ${ }^{29}$. Children are most likely to be infected, probably because of the association of their undeveloped immune system, the amount of eggs ingested ${ }^{19}$, and the frequency of reinfections ${ }^{30}$. Most patients who are seropositive for Toxocara spp. show no clinical signs ${ }^{7}$.
Human toxocariasis is classified in four forms: Systemic (classical and incomplete), Compartmentalized (ocular-OLM and neurologicalNLM), covert, and asymptomatic ${ }^{24,30}$. The classical form of VLM is characterized by high eosinophilia, fever, hepatosplenomegaly, hypergammaglobulinemia, and lung involvement, and affects mainly children ${ }^{9,30}$. In the visceral incomplete form, mainly hepatomegaly and high eosinophilia occurs. The NLM form is usually asymptomatic, although there may be symptoms ranging from minor neurological deficiencies to eosinophilic meningoencephalitis ${ }^{12}$. In OLM, low titers of anti-Toxocara spp. antibodies and discrete eosinophilia have been observed $^{7}$. This is a complex disease, for which the factors involved in its development and ocular compromise are still unknown ${ }^{4}$. The covert form is characterized by non-specific symptoms due to constant stimulus of parasite antigens on the host immune system; there may also be pulmonary involvement, such as asthma, acute bronchitis, dermatological disorders, myositis, lymphadenopathy, and pseudorheumatic syndromes such as arthralgia ${ }^{30}$.

The diagnosis of human toxocariasis is essentially based on immunological tests, because of the difficulty of locating larvae of Toxocara spp. in biopsy tissue. The prime diagnostic method is the

(1) Laboratório de Parasitologia Básica, Universidade Estadual de Maringá, Av. Colombo 5790, B1 I-90 Departamento de Análises Clínicas, 87020-900 Maringá, PR, Brasil

(2) Laboratório de Ciências Ambientais, Universidade Estadual de Maringá, Av. Colombo 5790, B1 I-90 Departamento de Análises Clínicas, $87020-900$ Maringá, PR, Brasil.

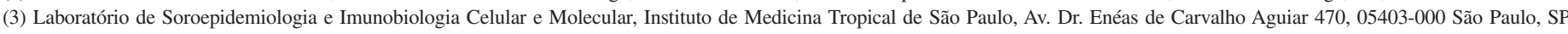
Brasil.

(4) Laboratório de Análises Clínicas, Hospital Municipal de Maringá, R. Vereador Gerson Soares da Costa Kuriango s/n, 87053-270 Maringá, PR, Brasil

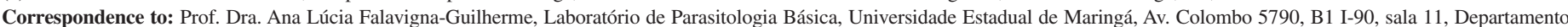
de Análises Clínicas, 87020-900 Maringá, PR, Brasil. Phone: +55.44.3261-4877, Fax: +55.44.3261-4860. E-mail: alfguilherme@uem.br 


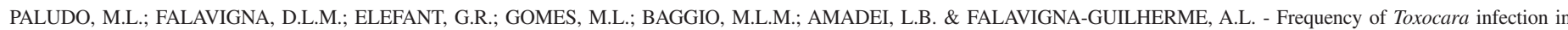
children attended by the health public service of Maringá, South Brazil. Rev. Inst. Med. trop. S. Paulo, 49(6): 343-348, 2007.

ELISA (Enzyme-Linked Immunosorbent Assay) test using the excretory-secretory antigens of infective larvae of Toxocara canis $^{13}$.

Studies in Brazil have reported prevalences from $2 \%$ to $54 \% \%^{2,5,10,16,25}$. Toxocariasis is usually neglected by the Brazilian Public Health Service, and is often not mentioned in medical courses. Cases of toxocariasis involving the eyes, liver, lungs, or brain may be detected by the use of immunological tests in seroprevalence assays ${ }^{28}$.

The lack of epidemiological data for toxocariasis in the state of Paraná, as well as the high frequency of eggs of Toxocara spp. found in public squares and lawns in the urban area of the city of Maringá ${ }^{34}$ justified the present assessment. The objective of this investigation was to determine the frequency of Toxocara spp. infection in child patients attended by the ambulatory service of the Maringá Municipal Hospital (MMH), and to associate them with epidemiological and clinical data.

\section{MATERIAL AND METHODS}

An observable cross-section study with incomplete selection was carried out. The study was approved by the institutional Research Ethics Committee (COPEP/UEM-305/2004), and by the MMH administrators. The individuals were invited to participate and informed in detail about the research, and voluntary written consent was obtained from the subjects enrolled.

Sampling: Based on the survey of the 2003-2004 annual statistics of 14,690 children attended by the Maringá Municipal Hospital, Paraná State, aged seven months to twelve years, 450 samples of blood were randomly collected from male and female patients, from September 2004 to September 2005. The size of the sample was calculated from an expected prevalence of $25 \%$, with a confidence interval (CI) of $95 \%$. This hospital serves exclusively users of the Brazilian Public Health System.

Serology: Blood samples were collected at the MMH ambulatory clinic, from patients referred for laboratory examinations (hematological and biochemical tests). The serum was preserved with buffered glycerin (1:1) and stored at $-20^{\circ} \mathrm{C}$ until it was analyzed. IgG anti-Toxocara spp. antibodies were investigated by the ELISA method, by means of a Toxocara excretory-secretory antigen (TES) from secondstage $T$. canis larvae obtained according to DE SAVIGNY et al. ${ }^{13}$, modified by ELEFANT et al. ${ }^{15}$. Reactive serum, non-reactive serum, and limiar reactive serum (LRS) were used in the entire survey. The ELISA cut-off was determined each time, using human positive and negative sera. The serologic results were considered reactive when the dilution of the serum showed an optical density (OD) of absorbance equal or higher than the cut-off. The results were expressed as the Index of Reactivity (IR) = optical density of the sample/optical density of LRS. Reacting samples were considered as those which showed IR $\geq 1$. All samples were tested in duplicate. This assay showed $78 \%$ sensitivity and $92 \%$ specificity.

Hemogram: The hemogram was done at the MMH Laboratory of Clinical Analyses, and the data for eosinophilia and hypochromia were compiled.
Clinical and epidemiological data: In order to evaluate possible risk factors for toxocariasis, the participants completed a questionnaire to obtain information about epidemiological data including: onicophagy habit; cats or dogs at the home; peridomestic exposed soil, grass, and sandbox; place where the child usually played (school or daycare center); whether the child played often in the public square with a sandbox, grass, or exposed soil; whether the child played in other locations with a sandbox, grass, or exposed soil; family income; age; sex; location of the home. The questionnaire also requested clinical data such as bronchitis, asthma, fever, pneumonia, cold, cough, diarrhea and vomiting, cephalia, pruritus or widespread eczema, or pain in the lower limbs.

Statistical analysis: A database was established using Microsoft Excel $^{\circledR} 2000$ and Statistics Version 6.0. A nonparametric Chi-square $\left(\chi^{2}\right)$ test was performed to compare the frequency of infected or uninfected children with each epidemiological, clinical, and hematological parameter investigated, using $\mathrm{p} \leq 0.05$ as the level of significance.

\section{RESULTS}

A total of 130 children (28.8\%) were positive for Toxocara spp. There was no significant difference between sexes $(p=0.297)$. Most seropositive children were from seven months to five years old (Table $1)$.

Table 1

Frequency of Toxocara spp. infection among children aged seven months to 12 years old attended by the Maringá Municipal Hospital (MMH), Paraná

\begin{tabular}{|c|c|c|c|c|c|}
\hline & \multicolumn{2}{|c|}{ Examined $(\%)$} & \multicolumn{2}{|c|}{ Positive (\%) } & $\mathrm{p}^{*}$ \\
\hline \multicolumn{6}{|c|}{ Age group (years) } \\
\hline $7 m-5 y$ & 294 & $(65.3)$ & 83 & $(28.2)$ & 0.0016 \\
\hline$>5 y-12 y$ & 156 & $(34.7)$ & 47 & $(30.1)$ & \\
\hline Total & 450 & & 130 & & \\
\hline \multicolumn{6}{|l|}{ Sex } \\
\hline Male & 223 & $(49.6)$ & 66 & $(50.8)$ & 0.9013 \\
\hline Female & 227 & $(50.4)$ & 64 & $(49.2)$ & \\
\hline
\end{tabular}

There was an important significant correlation between positive serology for toxocariasis, and frequent playing in a sandbox at the school or daycare center $(\mathrm{OR}=1.933)$ and the presence of a cat at home $(\mathrm{OR}=1.957)($ Table 2$)$.

The children came from different urban neighborhoods of Maringá. Most of the families (92\%) had an income from one to three minimum wages.

The signs and symptoms revealed upon examination by $\mathrm{MMH}$ pediatricians could not be correlated with positive serology for Toxocara spp. (Table 3). Nor could eosinophilia and hypochromia except for hypochromia at ages from seven months to two years $(\mathrm{p}=0.0001)$. For two children who presented bronchopneumonia, one two years old and the other one year old, the antibodies of both showed high titers 


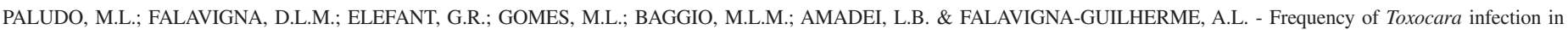
children attended by the health public service of Maringá, South Brazil. Rev. Inst. Med. trop. S. Paulo, 49(6): 343-348, 2007.

Table 2

Possible risk factors observed in children positive for Toxocara IgG antibody attended by the ambulatory service of the Maringá Municipal Hospital, Paraná, 2004 - 2005

\begin{tabular}{|c|c|c|c|c|c|c|}
\hline Variable & Group & Seropositive $(\%)$ & Seronegative $(\%)$ & Odds Ratio & $\mathrm{p}^{*}$ & IC \\
\hline \multirow[t]{2}{*}{ Onicophagy } & Yes & $57(43.8)$ & $131(40.9)$ & 1.127 & 0.570 & $(0.746 ; 1.701)$ \\
\hline & No & $73(56.2)$ & $189(59.1)$ & & & \\
\hline \multirow[t]{2}{*}{ Dog } & Yes & $78(60.0)$ & $192(60.0)$ & 1.000 & 1.000 & $(0.660 ; 1.516)$ \\
\hline & No & $52(40.0)$ & $128(40.0)$ & & & \\
\hline \multirow[t]{2}{*}{ Cat } & Yes & $15(11.5)$ & $20(6.2)$ & 1.957 & 0.056 & $(0.968 ; 3.952)$ \\
\hline & No & $115(88.5)$ & $300(93.8)$ & & & \\
\hline \multirow[t]{2}{*}{ Sand ${ }^{1}$} & Yes & $15(11.5)$ & $39(12.2)$ & 0.940 & 0.840 & $(0.499 ; 1.771)$ \\
\hline & No & $115(88.5)$ & $281(87.8)$ & & & \\
\hline \multirow[t]{2}{*}{ Soil ${ }^{1}$} & Yes & $76(58.5)$ & $182(56.9)$ & 1.067 & 0.757 & $(0.706 ; 1.613)$ \\
\hline & No & $54(41.5)$ & $138(43.1)$ & & & \\
\hline \multirow[t]{2}{*}{ Grass ${ }^{1}$} & Yes & $47(36.2)$ & $90(28.1)$ & 1.447 & 0.093 & $(0.939 ; 2.231)$ \\
\hline & No & $83(63.8)$ & $230(71.9)$ & & & \\
\hline \multirow[t]{2}{*}{ Sand $^{2}$} & Yes & $16(12.3)$ & $37(11.6)$ & 1.073 & 0.824 & $(0.574 ; 2.007)$ \\
\hline & No & $114(87.7)$ & $283(88.4)$ & & & \\
\hline \multirow[t]{2}{*}{ Soil $^{2}$} & Yes & 45 (34.6) & $111(34.7)$ & 0.997 & 0.988 & $(0.650 ; 1.530)$ \\
\hline & No & $85(65.4)$ & $209(65.3)$ & & & \\
\hline \multirow[t]{2}{*}{ Grass $^{2}$} & Yes & $25(19.2)$ & $54(16.9)$ & 1.173 & 0.550 & $(0.694 ; 1.983)$ \\
\hline & No & $105(80.8)$ & $266(83.1)$ & & & \\
\hline \multirow[t]{2}{*}{ Sand $^{3}$} & Yes & $30(23.1)$ & $43(13.4)$ & 1.933 & 0.011 & $(1.150 ; 3.249)$ \\
\hline & No & $100(76.9)$ & 277 (86.6) & & & \\
\hline \multirow[t]{2}{*}{ Soil ${ }^{3}$} & Yes & $22(16.9)$ & $36(11.3)$ & 1.607 & 0.103 & $(0.904 ; 2.855)$ \\
\hline & No & $108(83.1)$ & $284(88.8)$ & & & \\
\hline \multirow[t]{2}{*}{ Grass $^{3}$} & Yes & $31(23.8)$ & $72(22.5)$ & 1.079 & 0.758 & $(0.666 ; 1.745)$ \\
\hline & No & $99(76.2)$ & $248(77.5)$ & & & \\
\hline
\end{tabular}

${ }^{1}$ Present in backyards; ${ }^{2}$ In other areas where the child usually plays; ${ }^{3}$ Present at the school; $*($ Chi-square test, $\mathrm{p} \leq 0.05)$.

$(1: 10,240)$. Both children played on exposed soil and owned more than one dog. The hemogram of the 2-year-old indicated eosinophilia of 24,000 eosinophils $/ \mathrm{mm}^{3}$ and that of the 1-year-old revealed eosinophilia of 2,755 eosinophils $/ \mathrm{mm}^{3}$. Treatment with thiabendazole caused reversion of the clinical picture in one child. The other child was not located after the initial examination.

\section{DISCUSSION}

The seroprevalence observed in children who were attended at the MMH ambulatory clinic was similar to that shown by children at public hospitals in other Brazilian cities such as Campo Grande (Mato Grosso do Sul State) and Brasília (Federal District) with $35.5 \%$ and $21.8 \%$ seropositivity, respectively ${ }^{10,25}$. The MMH provides only public-health services for children from the districts and the city of Maringá. A higher prevalence $\left(54.8 \%\right.$ ) was observed by FIGUEIREDO et al. ${ }^{16}$ in 208 children from one to 14 years old who were attended at the Pediatric, Immunology and Pneumology ambulatory clinics of the University of Santo Amaro in the city of São Paulo. This finding differed from ours because the latter clinic provides specialized care to ambulatory patients; the children are from the periphery (mostly shantytowns) of São Paulo, and half of them were asthmatic. The seroprevalence of toxocariasis is closely related to the hygienic conditions found among people from different sociocultural and economic classes ${ }^{11}$. As in the reports of ALDERETE et al. ${ }^{2}$, ALONSO et al. ${ }^{3}$, ALTCHEH et al. ${ }^{4}$, FIGUEIREDO et al. ${ }^{16}$ and MAGNAVAL et al. ${ }^{23}$ there was no statistical difference in seroprevalence of this parasitosis between the genders.

Of 130 seropositive children, $64 \%$ were from seven months to five years old. The result of this assay may have been influenced by the high number of children of this age who were attended at the MMH ambulatory clinic. During their early years, children seem to be more often exposed to numerous infections because of the frequent contact with contaminated soil or sand by animal feces ${ }^{3,19,33}$. It was observed a higher prevalence of anti-Toxocara spp. antibodies in children until five years old, and ALDERETE et al. ${ }^{2}$ reported the highest positivity rate in four-year-old children. On the other hand, MURADIAN et al. ${ }^{26}$ observed only $14 \%$ of positivity in children from one to five years old, and higher percentages in older children.

In Brazil, the test for toxocariasis is unavailable through the publichealth services, although the ELISA method is inexpensive. This method has been recommended as a first-line test to detect toxocariasis, despite its $78 \%$ sensitivity. The possibility of a cross-reaction with Ascaris lumbricoides was minimized in our study, because the sera from all the patients were adsorbed with $A$. suum antigen before the test. This procedure avoided the use of other tests such as the Western blot concomitantly with the ELISA ${ }^{21}$.

Playing in a sandbox at the school or daycare center was the epidemiological factor most closely related to the prevalence of toxocariasis in Maringá, in children of all ages. We believe that this 


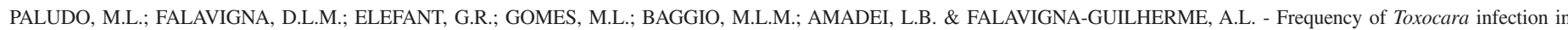
children attended by the health public service of Maringá, South Brazil. Rev. Inst. Med. trop. S. Paulo, 49(6): 343-348, 2007.

Table 3

Signs and symptoms diagnosed in children positive for Toxocara IgG antibody attended by the ambulatory service of Maringá Municipal Hospital, 2004 2005

\begin{tabular}{|c|c|c|c|c|}
\hline & $\begin{array}{l}\text { Seropositive }(\%) \\
\quad(\mathrm{n}=118)\end{array}$ & $\begin{array}{l}\text { Odds } \\
\text { Ratio }\end{array}$ & IC & $\mathrm{p}^{*}$ \\
\hline \multicolumn{5}{|l|}{ Fever } \\
\hline Yes & $62(52.5)$ & 1.026 & $(0.669 ; 1.575)$ & 0.992 \\
\hline No & $56(47.5)$ & & & \\
\hline \multicolumn{5}{|c|}{ Pneumonia } \\
\hline Yes & $7(5.9)$ & 1.976 & $(0.718 ; 5.435)$ & 0.289 \\
\hline No & $111(94.1)$ & & & \\
\hline \multicolumn{5}{|c|}{ Cold-like symptoms } \\
\hline Yes & $15(12.7)$ & 1.549 & $(0.785 ; 3.056)$ & 0.277 \\
\hline No & $103(87.3)$ & & & \\
\hline \multicolumn{5}{|l|}{ Cough } \\
\hline Yes & $23(19.5)$ & 0.894 & $(0.524 ; 1.527)$ & 0.783 \\
\hline No & $95(80.5)$ & & & \\
\hline \multicolumn{5}{|c|}{ Gastrointestinal problems } \\
\hline Yes & $49(41.5)$ & 0.943 & $(0.611 ; 1.454)$ & 0.877 \\
\hline No & $69(58.5)$ & & & \\
\hline \multicolumn{5}{|c|}{ Migraine } \\
\hline Yes & $15(12.7)$ & 0.941 & $(0.497 ; 1.781)$ & 0.979 \\
\hline No & $103(87.3)$ & & & \\
\hline \multicolumn{5}{|c|}{ Abdominal pain } \\
\hline Yes & $10(8.5)$ & 0.943 & $(0.440 ; 2.023)$ & 0.965 \\
\hline No & $108(91.5)$ & & & \\
\hline \multicolumn{5}{|c|}{ Joint pain } \\
\hline Yes & $2(1.7)$ & 0.9862 & $(0.188 ; 5.156)$ & 0.686 \\
\hline No & $116(98.3)$ & & & \\
\hline \multicolumn{5}{|c|}{ Skin rash } \\
\hline Yes & $8(6.8)$ & 2.573 & $(0.942 ; 7.024)$ & 0.105 \\
\hline No & $110(93.2)$ & & & \\
\hline
\end{tabular}

*Chi-square test $(\mathrm{p} \leq 0.05)$

correlation is due to the fact that the sandboxes frequently remain uncovered, allowing stray animals to use them when classes are not in session. A quantitative study of sand in public squares of this city, in winter and summer, found that Toxocara spp. eggs were widely distributed, comprising $50 \%$ of the parasite structures found ${ }^{34}$. ALDERETE et al. ${ }^{2}$ observed that eggs of Toxocara spp. were found in at least one sample of soil from each of five schools investigated. ZUNINO et al..$^{36}$ reported that these structures were those most often diagnosed in fecal material collected from urban public parks in Chubut, Argentina. In Rio de Janeiro, other factors such as the presence of puppies in the home and contact with soil contributed to seropositivity in children attended by a hospital ambulatory clinic ${ }^{16}$.

Other factors, such as the presence of cats in domiciles and contact with grass in the backyard during play periods, also contributed to the increase in the toxocariasis rate in the present investigation. Some epidemiological studies have attempted to identify risk factors for acquiring toxocariasis ${ }^{5,19,21}$. These factors range from the male gender ${ }^{21}$ to residence in a shantytown and a residence with a dirty backyard ${ }^{2}$. WOLFE \& WRIGHT ${ }^{35}$ reported that embryonated $T$. canis eggs were present in $4.2 \%$ of hair samples collected from $60 \mathrm{dogs}$, showing that direct contact with infected animals could transmit toxocariasis. However, contact with soil contaminated by cat and dog feces may be the main cause of the observed seropositivity. It has been reported that the risk factor for toxocariasis is contact with soil contaminated with cat or dog feces, rather than owning a cat or dog at home ${ }^{1,27}$.

Regarding the symptoms and signs, two children showed positive serology for Toxocara spp., presenting both bronchopneumonia and high eosinophilia. There is a strong association between positive serology for $T$. canis and eosinophilia and $\operatorname{IgE}^{18,26}$. JACOB et al. ${ }^{20}$ described an association between the VLM syndrome and bronchial spasms, pneumonia, and respiratory insufficiency. We know that clinical manifestations are variable and that they depend on the number of eggs ingested, the tissue involved, and the allergic response by the host ${ }^{17,26}$. Most of the time, toxocariasis can occur without symptoms $s^{14,24,30}$, being related to low ELISA titers ${ }^{22}$. Because there were few symptomatic children in this study, caution should be employed when interpreting positive results through population screening. For the most part, these could represent past exposure to the parasite rather than recent infection ${ }^{24}$. It is necessary to remember that human toxocariasis is a chronic infection, which may last for a number of years, and reactivated larvae may migrate into the eye or the brain at any time ${ }^{30}$.

This study established that toxocariasis is an infection that occurs in South Brazil, and is related to environmental contamination, mainly of sandboxes of schools and daycare centers by animal feces. The prevalence of this parasitosis could be investigated if $T$. canis antigen were available in the health care services to perform toxocariasis diagnosis as early as possible, thus aiding the medical professionals in the ready recognition and treatment of symptomatic cases. It has also emphasized the need to develop educational campaigns in the education and health services, to improve measures for the sanitary control of pets and stray dogs and cats, and cleanliness and monitoring of recreational areas.

\section{RESUMO}

\section{Freqüência de infecção por Toxocara em crianças atendidas em serviço público de Maringá, sul do Brasil}

A falta de métodos de diagnóstico laboratorial específico e sintomas específicos fazem da toxocaríase uma doença negligenciada nos serviços públicos de saúde. Este estudo teve por objetivo determinar a frequiência de infecção por Toxocara spp. em crianças atendidas no serviço público do Hospital Municipal de Maringá, sul do Brasil, e avaliar a associação com dados epidemiológicos e clínicos, em estudo observacional e transversal. De 14.690 crianças/ano atendidas, com idade entre sete meses a 12 anos, foram coletados 450 soros de setembro/2004 a setembro/2005. Um questionário foi utilizado para avaliar dados epidemiológicos, clínicos e hematológicos. Pelo teste ELISA, com antígeno de excreção/secreção de larvas de Toxocara canis, detectou-se $130(28,8 \%)$ soros positivos, principalmente em crianças entre sete meses e cinco anos $(\mathrm{p}=0,0016)$. Houve significante correlação entre sorologia positiva para Toxocara e freqüente recreação das crianças em caixas de areia da escola ou pré escola $(\mathrm{p}=0,011)$ e presença do gato no domicilio $(\mathrm{p}=0,056)$. Das famílias dessas crianças, 


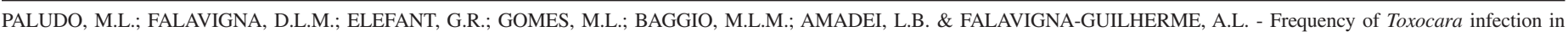
children attended by the health public service of Maringá, South Brazil. Rev. Inst. Med. trop. S. Paulo, 49(6): 343-348, 2007.

$50 \%$ possuíam cachorros e o quintal com solo exposto. Eosinofilia ( $\mathrm{p}$ $=0,776$ ), sinais e sintomas (febre $\mathrm{p}=0,992$, pneumonia $\mathrm{p}=0,289$, resfriado $\mathrm{p}=0,277$, tosse $\mathrm{p}=0,783$, problema gastrointestinal $\mathrm{p}=$ 0877 , dor de cabeça $\mathrm{p}=0,979$, dor abdominal $\mathrm{p}=0,965$, dores articulares $\mathrm{p}=0,686$, urticária $\mathrm{p}=0,105)$ não se correlacionaram com a soropositividade. Todavia, duas crianças asmáticas apresentaram títulos de 1:10.240 ( $\geq 1: 320)$ e acentuada eosinofilia $(\mathrm{p}=0.0001)$. Os autores enfatizam a necessidade de atividades preventivas.

\section{ACKNOWLEDGMENTS}

Authors wish to thanks IMT especially for providing antigens extracts and reference serum sample. We wish to express our thakfulness to Dra Marcia Oliveira, Thais Verzignassi Silveira and Dra Sandra Arraes - Immunology Section of UEM .

\section{REFERENCES}

1. AJAYI, O.O.; DUHLINSKA, D.D.; AGWALE, S.M. \& NJOKU, M. - Frequency of human toxocariasis in Jos, Plateau State, Nigeria. Mem. Inst. Oswaldo Cruz, 95: 147-149, 2000

2. ALDERETE, J.M.S; JACOB, C.M.A.; PASTORINO, A.C. et al. - Prevalence of Toxocara infection in schoolchildren from the Butantã region, São Paulo, Brazil. Mem. Inst. Oswaldo Cruz, 98: 593-597, 2003.

3. ALONSO, J.M.; BOJANICH, M.V.L.; CHAMORRO, M. \& GORODNER, J.O. - Toxocara seroprevalence in children from a subtropical city in Argentina. Rev. Inst. Med. trop. S. Paulo, 42: 235-237, 2000.

4. AltCheH, J.; NALlAR, M.; CONCA, M.; BIANCARDI, M. \& FREILIJ, H. Toxocariasis: clinical and laboratory features in 54 patients. An. Pediat. (Barcelona), 58: $425-431,2003$.

5. ANARUMA FILHO, F.; CHIEFFI, P.P.; CORREA, C.R.S. et al. - Human toxocariasis: a serum epidemiological survey in the municipality of Campinas(SP), Brazil. Rev. Inst. Med. trop. S. Paulo, 44: 303-307, 2002.

6. ANARUMA FILHO, F.; CHIEFFI, P.P.; CORREA, C.R.S. et al. - Human toxocariasis: incidence among residents in the outskirts of Campinas, State of São Paulo, Brazil. Rev. Inst. Med. trop. S. Paulo, 45: 293-294, 2003.

7. BASS, J.L.; MEHTA, K.A.; GLICKMAN, L.T. \& EPPES, B.M. - Clinically inapparent Toxocara infection in children. New Engl. J. Med., 308: 723-724, 1983.

8. BEAVER, P.C. - Larva migrans. Exp. Parasit., 5: 587-621, 1956.

9. BEAVER, P.C.; SNYDER, C.H.; CARRERA, G.M.; DENT, J.H. \& LAFFERTY, J.W. Chronic eosinophilia due to visceral larva migrans. Report of three cases. Pediatrics, 9: 7-19, 1952

10. CAMPOS Jr., D.; ELEFANT, G.R.; SILVA, E.O.M. et al. - Freqüência de soropositividade para antígenos de Toxocara canis em crianças de classes sociais diferentes. Rev. Soc. bras. Med. trop., 36: 509-513, 2003.

11. CHIEFFI, P.P.; UEDA, M.; CAMARGO, E.D. et al. - Visceral larva migrans: a seroepidemiological survey in five municipalities of São Paulo State, Brazil. Rev. Inst. Med. trop. S. Paulo, 32: 204-210, 1990.

12. COX, D.M. \& HOLLAND, C.V. - The relationship between numbers of larvae recovered from the brain of Toxocara canis-infected mice and social behaviour and anxiety in the host. Parasitology, 116: 579-594, 1998.

13. DE SAVIGNY, D.H.; VOLLER, A. \& WOODRUFF, A.W. - Toxocariasis: serological diagnosis by enzyme immunoassay. J. clin. Path., 32: 284-288, 1979.
14. DI BARTOLOMEO, S.; ALONSO, L.; DOBLORES, A. et al. - Eosinofilia: ¿Principal parametro para la detección de toxocarosis? Acta bioquim. clín. lat.-amer., 4: 527$530,2001$.

15. ELEFANT, G.R.; JACOB, C.M.A.; KANASHIRO, E.H.Y. \& PERES, B.A. - Toxocaríase In: FERREIRA, A.W. \& AVILA, S.L.M., ed. Diagnóstico laboratorial das principais doenças infecciosas e auto-imunes. 2. ed. Rio de Janeiro, Guanabara Koogan, 2001. p. 323-332.

16. FIGUEIREDO, S.D.P.; TADDEI, A.A.C.; MENEZES, J.J.C. et al. - Estudo clínicoepidemiológico da toxocaríase em população infantil. J. Pediat. (Rio de J.), 81: 126-132, 2005.

17. GLICKMAN, L.T. \& SHOFER, F.S. - Zoonotic visceral and ocular larva migrans. Vet. Clin. N. Amer. small Anim. Pract., 17: 39-53, 1987.

18. GLICKMAN, L.T.; MAGNAVAL J.F.; DOMANSKI, L.M. et al. - Visceral larva migrans in French adults: a new disease syndrome? Amer. J. Epidem., 125: 1019-1034, 1987.

19. HABLUETZEL, A.; TRALDI, G.; RUGGIERI, S. et al. - An estimation of Toxocara canis prevalence in dogs, environmental egg contamination and risk of human infection in the Marché region of Italy. Vet. Parasit., 113: 243-252, 2003.

20. JACOB, C.M.A.; PASTORINO, A.C.; PERES, B.A. et al. - Clinical and laboratorial features of visceral toxocariasis in infancy. Rev. Inst. Med. trop. S. Paulo, 36: 1926, 1994.

21. KANAFANI, Z.A.; SCHOURY, A.; ARAJ, G.F. et al. - Seroprevalence of toxocariasis in Lebanon: a pilot study. Parasitology, 132: 635-639, 2006.

22. LUZNA-LYSKOV, A.; ANDRZEJEWSKA, I.; LESICKA, U. et al.- Clinical interpretation of eosinophilia and ELISA values (OD) in toxocarosis. Acta parasit., 45: 35-39, 2000 .

23. MAGNAVAL, J.F.; MICHAULT, A.; CALON, N. \& CHARLET, J.P. - Epidemiology of human toxocariasis in La Reunion. Trans. roy. Soc. trop. Med. Hyg., 88: 531-533, 1994.

24. MAGNAVAL, J.F.; GLICKMAN, L.T.; DORCHIES, P. \& MORASSIN, B. - Highlights of human toxocariasis. Korean J. Parasit., 39: 1-11, 2001.

25. MATOS, M.F.; MILITÃO, D.N.A.; BRUM, M.A.R. et al. - Presence of anti-Toxocara antibodies in children selected at Hospital Universitário, Campo Grande, MS, Brazil. Rev. Inst. Med. trop. S. Paulo, 39: 49-50, 1997.

26. MURADIAN, V.; GENNARI, S.M.; GLICKMAN, L.T. \& PINHEIRO, S.R. Epidemiological aspects of Visceral Larva Migrans in children living at São Remo Community, São Paulo (SP), Brazil. Vet. Parasit., 134: 93-97, 2005.

27. OVERGAAUW, P.A. - Aspects of Toxocara epidemiology: human toxocarosis. Crit. Rev. Microbiol., 23: 215-231, 1997.

28. PARK, H.Y.; LEE, S.U.; HUH, S.; KONG, Y. \& MAGNAVAL, J.F. - A seroepidemiological survey for toxocariasis in apparently healthy residents in Gangwon-do, Korea. Korean J. Parasit., 40: 113-117, 2002.

29. PARSONS, J.C.; BOWMAN, D.D. \& GRIEVE, R.B. - Tissue localization of excretorysecretory antigens of larval Toxocara canis in acute and chronic murine toxocariasis. Amer. J. trop. Med. Hyg., 35: 974-981, 1986.

30. PAWLOWSKI, Z. - Toxocariasis in humans: clinical expression and treatment dilemma. J. Helminth., 75: 299-305, 2001.

31. RADMAN, N.E.; ARCHELLI, S.M.; FONROUGE, R.D.; GUARDIS, M. DEL V. \& LINZITTO, O.R. - Human toxocarosis. Its seroprevalence in the city of La Plata. Mem. Inst. Oswaldo Cruz, 95: 281-285, 2000.

32. SCHANTZ, P.M. - Toxocara Larva Migrans now. Amer. J. trop. Med. Hyg., 41: 21-34, 1989. 
PALUDO, M.L.; FALAVIGNA, D.L.M.; ELEFANT, G.R.; GOMES, M.L.; BAGGIO, M.L.M.; AMADEI, L.B. \& FALAVIGNA-GUILHERME, A.L. - Frequency of Toxocara infection in children attended by the health public service of Maringá, South Brazil. Rev. Inst. Med. trop. S. Paulo, 49(6): 343-348, 2007.

33. TIERNEY Jr., L.M.; McPHEE, S.J. \& PAPADAKIS, M.A. - Larva migrans visceral (toxocaríase). In: LANGE, L. Diagnóstico e tratamento. São Paulo, Atheneu, 2001. p. 1416-1417.

34. TIYO, R. - Contaminação ambiental de praças e gramados públicos de Maringá, estado do Paraná, Brasil, por helmintos e protozoários. Maringá, 2005. (Dissertação de Mestrado - Programa de Pós Graduação em Ciências da Saúde da Universidade Estadual de Maringá).
35. WOLFE, A. \& WRIGHT, I.P. - Human toxocariasis and direct contact with dogs. Vet. Rec., 152: 419-422, 2003.

36. ZUNINO, M.G.; DE FRANCESCO, M.V.; KURUC, J.A. et al. - Contaminación por helmintos en espacios públicos de la provincia de Chubut, Argentina. Bol. chil. Parasit., 55: 78-83, 2000.

Received: 27 October 2006

Accepted: 12 April 2007 